\title{
Knowledge acquisition and effective socialization: the role of the psychological contract
}

Article

Accepted Version

Woodrow, C. and Guest, D. E. (2017) Knowledge acquisition and effective socialization: the role of the psychological contract. Journal of Occupational and Organizational Psychology, 90 (4). pp. 587-595. ISSN 2044-8325 doi: https://doi.org/10.1111/joop.12178 Available at https://centaur.reading.ac.uk/67467/

It is advisable to refer to the publisher's version if you intend to cite from the work. See Guidance on citing.

To link to this article DOI: http://dx.doi.org/10.1111/joop.12178

Publisher: Wiley

All outputs in CentAUR are protected by Intellectual Property Rights law, including copyright law. Copyright and IPR is retained by the creators or other copyright holders. Terms and conditions for use of this material are defined in the End User Agreement.

www.reading.ac.uk/centaur 
Central Archive at the University of Reading

Reading's research outputs online 
Running head: PSYCHOLOGICAL CONTRACTS AND EFFECTIVE SOCIALIZATION

Knowledge Acquisition and Effective Socialization: The Role of the Psychological Contract

Chris Woodrow ${ }^{1}$ and David E Guest ${ }^{2}$

${ }^{1}$ Henley Business School, University of Reading, UK

2 School of Management \& Business, King's College London, UK

Word count (exc. figures/tables): 1995 words

*Requests for reprints should be addressed to Chris Woodrow, Henley Business School University of Reading, Whiteknights, Reading, RG6 6UD. Email:

c.woodrow@henley.ac.uk 
PSYCHOLOGICAL CONTRACTS AND EFFECTIVE SOCIALIZATION

\begin{abstract}
Although studies reveal that acquiring knowledge about a new workplace during organizational socialization leads to better integration, the pathway through which this occurs is not well understood. Previous research has explored the psychological contract as an outcome of socialization. This study explores its role within the socialization process. 161 organizational newcomers undertook surveys at months one and three of tenure, with data used to test a model within which four psychological contract dimensions mediate the relationship between knowledge acquisition and employee outcomes. At month one, organizational and employee promise strength mediated the relationship between knowledge and outcomes. At month three, organizational and employee promise fulfilment mediated this relationship. Findings confirm the role of the psychological contract in the socialization process and suggest that effective integration requires extensive knowledge provision and active employee knowledge acquisition.
\end{abstract}

Keywords: Psychological contract, Organizational socialization, Integration 
PSYCHOLOGICAL CONTRACTS AND EFFECTIVE SOCIALIZATION

\section{Practitioner Points}

- Acquisition of knowledge about a new work environment during the very early stages of tenure can positively affect newcomers' attitudes and perceived employment relationships.

- Learning leads to mutual promises that are perceived to be stronger and more likely to be fulfilled, as well as reduced stress, greater commitment and greater service quality behaviour.

- Employers should provide newcomers with information about their role, team and organization, whilst newcomers should be encouraged to ask questions. 
PSYCHOLOGICAL CONTRACTS AND EFFECTIVE SOCIALIZATION

\section{Knowledge acquisition and effective socialization: the role of the psychological contract}

Organizational socialization has been defined as the "process by which individuals become part of an organization's pattern of activities" (Ashforth, Slus and Harrison, 2007:1). A particularly important stage of socialization is encounter, which begins at day one and involves learning about the realities of organizational life. Whilst this learning is related to better integration, evidenced by a range of employee outcomes (Bauer, Bodner, Erdogan, Truxillo and Tucker, 2007), limited attention has been paid to the underlying mechanism at work.

This study aims to explore the role of one under-examined construct in the socialization process, namely the psychological contract, defined as the "individual beliefs, shaped by the organization, regarding terms of an exchange agreement between the individual and their organization" (Rousseau, 1995: 9). Although some previous studies have shown that perceptions of the content (Thomas and Anderson, 1998) or fulfilment (De Vos and Freese, 2011) of the psychological contract change during socialization, these have treated the psychological contract as an outcome of socialization. This study treats the psychological contract as an intervening variable in the socialization process, focusing on its role in the crucial encounter phase during the initial months after entry.

Theoretical basis and hypotheses

We propose that two psychological contract dimensions are critical for organizational socialization: newcomers' perceptions of how clearly and explicitly a promise has been made (“promise strength"), and the extent to which employees or employers are perceived to deliver perceived promises ("promise fulfilment"). The core of our theoretical approach is that socialization involves a period of uncertainty reduction and sensemaking, when newcomers are driven to make sense of their environment through a process of social 


\section{PSYCHOLOGICAL CONTRACTS AND EFFECTIVE SOCIALIZATION}

exchange. This process results in the formation of the psychological contract and, subsequently, determines employee outcomes. All hypotheses are shown in Figure 1.

Upon organizational entry, newcomers absorb information about their environment to reduce stressful uncertainty (Louis, 1980). The resulting socialization knowledge represents the content of what has been learnt during socialization. Three types of knowledge are necessary for effective integration, concerning the role, team and organization (Ashforth et al., 2007). Acquiring this knowledge enables newcomers to better understand the behaviours that are expected and inducements that are offered by the organization. This understanding takes the form of a cognitive schema, or psychological contract (Rousseau, 2001). Where employees have greater knowledge of their new environment, the promises that make up this perceived deal are more firmly encoded, reflected in perceptions of stronger two-way promises:

Hla: Socialization knowledge is positively related to organizational promise strength.

H2a: Socialization knowledge is positively related to employee promise strength.

Since the development of perceived promises reduces stressful uncertainty, we expect organizational promise strength to be related to a reduction of reported stress at three months. Additionally, we expect newcomers to more fully engage in pro-organizational behaviours when they are made strong promises, as they seek to return expected organizational contributions through the mechanism of social exchange:

H1b: Socialization knowledge is negatively related to experienced stress through the mediating role of organizational promise strength.

H2b: Socialization knowledge is positively related to employee service quality behaviour through the mediating role of employee promise strength.

After very early employment, information acquisition slows and perceived promises are altered less frequently (Shore and Tetrick, 1994). Socialization knowledge now influences 


\section{PSYCHOLOGICAL CONTRACTS AND EFFECTIVE SOCIALIZATION}

perceived organizational promise fulfilment, by determining congruence between the perceptions of newcomers and organizational agents (Morrison and Robinson, 1997). Likewise, we expect knowledge to clarify employees' own promises and increase employee fulfilment, since the norms of the new environment are more regularly reinforced and promises contain less ambiguity:

Hypothesis 3a: Socialization knowledge is positively related to perceived organizational promise fulfilment.

Hypothesis 4a: Socialization knowledge is positively related to perceived employee promise fulfilment.

Perceived fulfilment in turn affects employee outcomes. In line with social exchange theory, employees are expected to invest more in the relationship where the organization has upheld its side of the deal (Coyle-Shapiro and Kessler, 2000), reflected in increasing commitment across the encounter stage. Additionally, where employees fulfil their promises, it is expected they will have positive perceptions of their own behaviour, reflected, inter alia, in high quality service behaviour across this time period:

Hypothesis 3b: Socialization knowledge is positively related to affective commitment through the mediating role of perceived organizational promise fulfilment.

Hypothesis 4b: Socialization knowledge is positively related to employee service quality behaviour through the mediating role of perceived employee promise fulfilment.

In order to assess the hypotheses, a two-wave within-subjects design survey study collected data on the constructs of interest. 
PSYCHOLOGICAL CONTRACTS AND EFFECTIVE SOCIALIZATION

\section{Methods}

\section{$\underline{\text { Participant characteristics }}$}

Participants were new members of staff in a large UK hospital. Of the 345 newcomers who completed a survey at time one and consented to be contacted, $162(47 \%)$ responded at time two. Of these, $53.7 \%$ were nursing staff, $27.1 \%$ other health professionals and $19.2 \%$ administrative staff. Males made up $14.1 \%$ of the sample, and $41.4 \%$ were from a black and minority ethnic background. Participants ranged in age from 20 to 59 years, with a mean age of 33 years.

\section{$\underline{\text { Design and Procedure }}$}

Participants were recruited into the study with an initial survey during a number of organizational induction sessions that each newcomer is required to attend during their first month. A further survey was sent by email or post to participants following three months service. This is generally considered an acceptable time to assess the encounter stage (Bauer et al., 2007). All surveys were completed between 2010 and 2012.

\section{$\underline{\text { Measures }}$}

Details of all scales used, which were based upon previously validated measures, are shown in Table 1. In all cases, five-point response scales were used. Psychological contract measures were based upon those of Guest, Isaksson, and De Witte (2010), and were refined through pilot interviews ${ }^{1}$. Promise strength was assessed by asking participants the extent to which they (or their organization) had promised, either formally or informally, to provide various activities. Promise fulfilment was assessed by asking participants the extent to which each activity had been delivered. In line with previous accounts of socialization (e.g. Ashforth et al., 2007), newcomer socialization knowledge was assessed by asking 


\section{PSYCHOLOGICAL CONTRACTS AND EFFECTIVE SOCIALIZATION}

participants about their level of understanding of aspects of their role, team and organization, using ten items from Haueter, Macan and Winter (2003).

Experienced stress was assessed using three items developed by Smith (2001) and organizational commitment was assessed using four items from Meyer and Allen's (1997) Affective Commitment Scale. Service quality behaviour was assessed using five items adapted from Daniel and Darby (1997), concerning the extent to which participants engaged in context-specific service quality behaviours.

\section{Findings}

Hypotheses were tested through four mediated regression analyses, each consisting of two regression models (path $a$ and $b$ ). The results of these analyses are shown in Table 2. For each of the $a$ paths, socialization knowledge is positively associated with the corresponding psychological contract (mediating) variable, supporting Hypotheses 1a, 2a 3a and 4a. Analysis of $b$ paths also shows significant associations between each psychological contract (mediator) variable and each outcome variable.

For each of the four mediation models, bootstrapping analysis using 1000 samples was undertaken to assess the strength of any indirect effects. Hypotheses $1 b, 2 b$ and $3 b$ are fully supported, since the strength of the indirect effect is significantly different to 0 at the $95 \%$ confidence level. Hypothesis $4 \mathrm{~b}$ is also supported, although the relationship between promise fulfilment and service quality is significant only at the $90 \%$ confidence level.

\section{Discussion}

The overarching aim of this study was to investigate the role of the psychological contract as an intervening variable in the relationship between early knowledge acquisition and later employee outcomes. Analysis of the two-wave survey data supports all hypotheses. Perceived organizational promise strength mediates the relationship between knowledge 


\section{PSYCHOLOGICAL CONTRACTS AND EFFECTIVE SOCIALIZATION}

acquisition and stress, whilst perceived organizational promise fulfilment mediates the relationship between knowledge acquisition and commitment. Both the perceived strength and fulfilment of employee promises mediates the relationship between knowledge acquisition and service quality behaviour.

\section{Implications for theory}

The first implication of this study concerns the process of socialization. The psychological contract has previously been treated as an indicator of adjustment (e.g. De Vos and Freese, 2011; Thomas and Anderson, 1998). This study shows that the psychological contract is a crucial intervening variable during socialization, with perceived promise strength related to stress and service quality behaviour during early tenure, and promise fulfilment related to commitment and service quality behaviour at a later time.

A second implication concerns psychological contract formation. Previous theory suggests that the psychological contract develops through communication with organizational insiders during early tenure (e.g. Sherman and Morley, 2015). Studies have confirmed this, although these have focussed either on expectations (e.g. Thomas and Anderson, 1998) or on psychological contract-specific information (e.g. De Vos and Freese, 2011). This study shows that the knowledge that is required during socialization drives the psychological contract.

\section{Implications for practice}

In terms of practical implications, this study suggests that employers should provide newcomers with information, whilst encouraging them to ask questions, in order to foster a committed employment relationship and engender positive employee outcomes. Our research also suggests that to maximise employee outcomes, employee perceptions of both strong promises and their fulfilment is required. Whilst promises that cannot be fulfilled should not 


\section{PSYCHOLOGICAL CONTRACTS AND EFFECTIVE SOCIALIZATION}

be made, this implies that employers should communicate clearly with employees and seek to deliver upon promises, and that employees should do likewise.

\section{$\underline{\text { Limitations and future research }}$}

There are some limitations to the current study and several potentially fruitful avenues for further research. First, this research surveyed only newcomers to one organization and examined the psychological contract only from the perspective of the employee. Future studies should examine different contexts and explore how psychological contract perceptions of organizational agents are related to integration. Second, we examined only the effects of useful knowledge, as defined by previous research, about the role, team and organization. However, it is likely that other knowledge is acquired which may hasten exit rather than engender commitment. Future research might focus on the negative side of socialization. Third, we studied socialization during the first three months of employment. This was a deliberate choice based on evidence that these early months are the crucial period, but a longer follow-up period could reveal the persistence of attitudinal and behavioural outcomes. Finally, this study examined only one indicator of learning. Future research may examine different modes of information acquisition, such as information provided by the organization versus that actively sought by newcomers, as well as the role of trust in that information.

\section{Conclusion}

In conclusion, this study provides new insights into the socialization process and in particular the role of the psychological contract in that process, shedding new light on often-neglected features of the psychological contract, thereby enhancing the richness of the concept. 


\section{PSYCHOLOGICAL CONTRACTS AND EFFECTIVE SOCIALIZATION}

\section{References}

Ashforth, B. E, Sluss, D. M., \& Harrison, S. (2007). Socialization in organizational contexts. In G. P. Hodgkinson \& J. K. Ford (Eds.), International Review of Industrial and Organizational Psychology (pp. 1-70). Chichester, West Sussex: John Wiley \& Sons.

Bauer, T. N., Bodner, T., Erdogan, B., Truxillo, D. M., \& Tucker, J. S. (2007). Newcomer adjustment during organizational socialization: a meta-analytic review of antecedents, outcomes, and methods. Journal of Applied Psychology, 92(3), 707-721. doi: http://dx.doi.org/10.1037/0021-9010.92.3.707

Coyle-Shapiro, J. A. M., \& Kessler, I. (2000). Consequences of the psychological contract for the employment relationship: a large-scale survey. Journal of Management Studies, 37(7), 903-930. doi: 10.1111/1467-6486.00210

Daniel, K., \& Darby, D. N. (1997). A dual perspective of customer orientation: a modification, extension and application of the SOCO scale. International Journal of Service Industry Management, 8(2), 131-147. doi: 10.1108/09564239710166254

De Vos, A., \& Freese, C. (2011). Sensemaking during organizational entry: changes in newcomer information seeking and the relationship with psychological contract fulfilment. Journal of Occupational and Organizational Psychology, 84(2), 288-314. doi: 10.1111/j.2044-8325.2011.02024.x

Guest, D., Isaksson, K., \& De Witte, H. (2010). Employment contracts, psychological contracts, and worker well-being: An international study. Oxford: Oxford University Press.

Haueter, J. A., Macan, T. H., \& Winter, J. (2003). Measurement of newcomer socialization: Construct validation of a multidimensional scale. Journal of Vocational Behavior, 63(1), 20-39. doi:10.1016/S0001-8791(02)00017-9 


\section{PSYCHOLOGICAL CONTRACTS AND EFFECTIVE SOCIALIZATION}

Louis, M. R. (1980). Surprise and sense making: what newcomers experience in entering unfamiliar organizational settings. Administrative Science Quarterly, 25(2), 226-251. doi: 10.1300/J111V04N01_08

Meyer, J. P., \& Allen, N. J. (1997). Commitment in the Workplace: Theory, Research, and Application. Thousand Oaks, CA: Sage.

Morrison, E. W., \& Robinson, S. L. (1997). When employees feel betrayed: a model of how psychological contract violation develops. Academy of Management Review, 22(1), 226-256. doi: 10.5465/AMR.1997.9707180265

Rousseau, D. M. (1995). Psychological Contracts in Organizations: Understanding Written and Unwritten Agreements. Thousand Oaks, CA: Sage.

Rousseau, D. M. (2001). Schema, promise and mutuality: the building blocks of the psychological contract. Journal of Occupational and Organizational Psychology, 74(4), 511-541. doi: 10.1348/096317901167505

Sherman, U. P., \& Morley, M. J. (2015). On the formation of the psychological contract: A schema theory perspective. Group \& Organization Management, 40(2), 160-192. doi: $10.1177 / 1059601115574944$

Shore, L. M. \& Tetrick, L. E. (1994). The psychological contract as an explanatory framework in the employment relationship. In C. L. Cooper \& D. M. Rousseau (Eds.), Trends in Organizational Behavior (pp. 91-109). New York: Wiley.

Smith, A. (2001). Perceptions of stress at work. Human Resource Management Journal, 11(4), 74-86. doi: 10.1111/j.1748-8583.2001.tb00052.x

Thomas, H. D. C., \& Anderson, N. (1998). Changes in newcomers' psychological contracts during organizational socialization: a study of recruits entering the British Army. 
PSYCHOLOGICAL CONTRACTS AND EFFECTIVE SOCIALIZATION

Journal of Organizational Behavior, 19(S1), 745-767. doi: 10.1002/(SICI)10991379(1998)19:1+<745::AID-JOB967>3.0.CO;2 
PSYCHOLOGICAL CONTRACTS AND EFFECTIVE SOCIALIZATION

\section{Footnotes}

${ }^{1}$ Full details of the measures can be obtained from the first author

\section{Funding}

This paper presents independent research commissioned by the National Institute for Health Research (NIHR). The views expressed in this paper are those of the author(s) and not necessarily those of the NHS, NIHR or the Department of Health. Funding for the research was provided by the NIHR. 
Figure 1: Study hypotheses

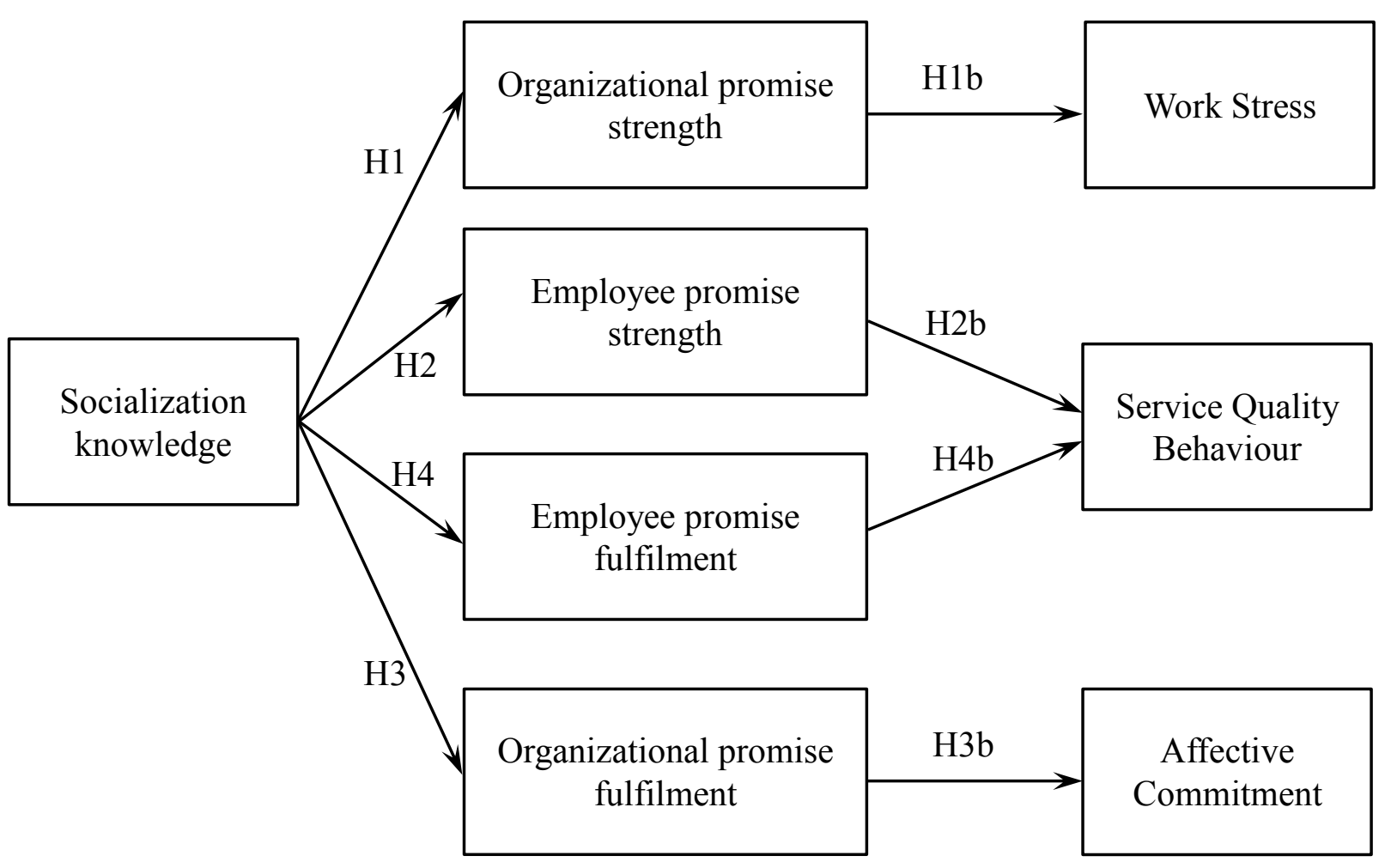




\section{PSYCHOLOGICAL CONTRACTS AND EFFECTIVE SOCIALIZATION}

\section{Table 1. Survey items, descriptive statistics and intercorrelations}

\begin{tabular}{|c|c|c|c|c|c|c|c|c|c|c|c|c|c|c|}
\hline Variable & Items & Source & Mean (SD) & $\alpha$ & 1 & 2 & 3 & 4 & 5 & 6 & 7 & 8 & 9 & 10 \\
\hline $\begin{array}{l}\text { 1 Socialization } \\
\text { knowledge (T1) }\end{array}$ & 12 & $\begin{array}{l}\text { Haueter, Macan and } \\
\text { Winter (2003) }\end{array}$ & $4.36(0.57)$ & 0.92 & & & & & & & & & & \\
\hline $\begin{array}{l}2 \text { Organizational } \\
\text { promise strength (T1) }\end{array}$ & 18 & $\begin{array}{l}\text { Guest, Isaksson, and } \\
\text { De Witte (2010) }\end{array}$ & $4.15(0.46)$ & -- & $.55 * * *$ & & & & & & & & & \\
\hline $\begin{array}{l}3 \text { Employee promise } \\
\text { strength (T1) }\end{array}$ & 19 & $\begin{array}{l}\text { Guest, Isaksson, and } \\
\text { De Witte (2010) }\end{array}$ & $4.65(0.46)$ & -- & $.51 * * *$ & $.55 * * *$ & & & & & & & & \\
\hline $\begin{array}{l}4 \text { Organizational } \\
\text { promise fulfilment } \\
\text { (T2) }\end{array}$ & 18 & $\begin{array}{l}\text { Guest, Isaksson, and } \\
\text { De Witte (2010) }\end{array}$ & $4.12(0.70)$ & -- & $.24 * * *$ & $.22 * * *$ & 0.11 & & & & & & & \\
\hline $\begin{array}{l}5 \text { Employee promise } \\
\text { fulfilment (T2) }\end{array}$ & 19 & $\begin{array}{l}\text { Guest, Isaksson, and } \\
\text { De Witte (2010) }\end{array}$ & $4.66(0.38)$ & -- & $.29 * * *$ & $.19 * *$ & 0.11 & $.49 * * *$ & & & & & & \\
\hline 6 Stress (T1) & 3 & Smith (2001) & $2.58(0.95)$ & 0.78 & -0.12 & -0.05 & 0.0 & $-.21 * *$ & -0.03 & & & & & \\
\hline $\begin{array}{l}7 \text { Affective } \\
\text { commitment (T1) }\end{array}$ & 4 & $\begin{array}{l}\text { Meyer and Allen } \\
\text { (1997) }\end{array}$ & $3.53(0.88)$ & 0.88 & $.34 * * *$ & $.31 * * *$ & 0.14 & 0.12 & $.21^{* *}$ & -0.1 & & & & \\
\hline $\begin{array}{l}8 \text { Service quality } \\
\text { behaviour (T1) }\end{array}$ & 5 & $\begin{array}{l}\text { Daniel and Darby } \\
\text { (1997) }\end{array}$ & $4.13(0.76)$ & 0.82 & $.34 * * *$ & $.29 * * *$ & 0.1 & $.26 * * *$ & $.28 * * *$ & 0.16 & 0.08 & & & \\
\hline 9 Stress (T2) & 3 & Smith (2001) & $2.82(1.16)$ & 0.85 & $-.22 * * *$ & $-.21 * * *$ & $-.16^{* *}$ & $-.25 * * *$ & -0.13 & $.52 * * *$ & $-.20 * *$ & -0.04 & & \\
\hline $\begin{array}{l}10 \text { Affective } \\
\text { commitment (T2) }\end{array}$ & 4 & $\begin{array}{l}\text { Meyer and Allen } \\
\text { (1997) }\end{array}$ & $3.40(0.96)$ & 0.90 & $.28 * * *$ & $.26^{* * * *}$ & $.17 * *$ & $.41 * * *$ & $.26 * * *$ & -0.14 & $.59 * * *$ & 0.14 & $-.22 * * *$ & \\
\hline $\begin{array}{l}11 \text { Service quality } \\
\text { behaviour (T2) }\end{array}$ & 5 & $\begin{array}{l}\text { Daniel and Darby } \\
\text { (1997) }\end{array}$ & $4.22(0.67)$ & 0.80 & $.18^{* *}$ & 0.15 & $.16^{* *}$ & $.34 * * *$ & $.31 * * *$ & 0.02 & 0.1 & $.57 * *$ & 0.0 & $.285^{* * *}$ \\
\hline
\end{tabular}




\section{PSYCHOLOGICAL CONTRACTS AND EFFECTIVE SOCIALIZATION}

Table 2: Mediation analyses

\begin{tabular}{|c|c|c|c|c|c|c|c|c|}
\hline & $\underline{\text { a path }(H 1)}$ & bpath $(H 1 b)$ & a path $(H 2)$ & bpath $(H 2 b)$ & a path $(H 3)$ & b path $(H 3 b)$ & a path $(H 4)$ & bpath $(H 4 b)$ \\
\hline & $\begin{array}{l}\text { Organizational } \\
\text { promise } \\
\text { strength }\end{array}$ & Stress & $\begin{array}{l}\text { Employee } \\
\text { promise } \\
\text { strength }\end{array}$ & $\begin{array}{l}\text { Service } \\
\text { Quality }\end{array}$ & $\begin{array}{l}\text { Organizational } \\
\text { Promise } \\
\text { fulfilment }\end{array}$ & Commitment & $\begin{array}{l}\text { Employee } \\
\text { Promise } \\
\text { Fulfilment }\end{array}$ & $\begin{array}{l}\text { Service } \\
\text { Quality }\end{array}$ \\
\hline \multicolumn{9}{|l|}{ Control variables } \\
\hline Age & -0.04 & -0.11 & 0.03 & 0.05 & 0.00 & -0.06 & 0.015 & 0.04 \\
\hline $\mathrm{DV}$ at $\mathrm{T} 1$ & & $0.48 * * *$ & & $0.60 * * *$ & & $0.56 * * *$ & & $0.56^{* * *}$ \\
\hline \multicolumn{9}{|l|}{ Independent variables } \\
\hline Socialization knowledge & $0.55 * * *$ & -0.44 & $0.51 * * *$ & -0.10 & $0.24 * *$ & 0.002 & $0.30^{* * *}$ & -0.08 \\
\hline \multicolumn{9}{|l|}{ Mediator } \\
\hline Promise strength & & $-0.19^{*}$ & & $0.23^{*}$ & & & & \\
\hline Promise fulfilment & & & & & & $0.35 * * *$ & & $0.15^{\dagger}$ \\
\hline \multicolumn{9}{|l|}{$\underline{\text { Model statistics }}$} \\
\hline $\mathrm{N}$ & 147 & 141 & 147 & 118 & 147 & 141 & 146 & 117 \\
\hline $\mathrm{F}$ & $31.80 * * *$ & $14.83 * * *$ & $25.50^{* * * *}$ & $16.36^{* * * *}$ & 4.36 & $31.05 * * *$ & $7.27 * *$ & $15.49^{* * *}$ \\
\hline Control $\Delta \mathrm{R}^{2}$ & 0 & $0.26^{* * *}$ & 0.01 & $0.34^{* * *}$ & 0 & $0.36^{* * * *}$ & 0.00 & $0.34 * * *$ \\
\hline $\mathrm{IV} \Delta \mathrm{R}^{2}$ & $0.31 * * *$ & 0.2 & $0.26^{* * * *}$ & 0.00 & $0.06^{* *}$ & 0.01 & $0.09^{* * *}$ & 0.00 \\
\hline $\mathrm{M} \Delta \mathrm{R}^{2}$ & & $0.24 *$ & & $0.03^{*}$ & & $0.11^{* * * *}$ & & $0.02^{\dagger}$ \\
\hline Bootstrap CI for indirect effect ${ }^{\mathrm{a}}$ & \multicolumn{2}{|c|}{$(-0.48,-0.01)$} & \multicolumn{2}{|c|}{$(0.027,0.182)$} & \multicolumn{2}{|c|}{$(0.0563,0.301)$} & \multicolumn{2}{|c|}{$(0.0018,0.1556)$} \\
\hline
\end{tabular}

Note $. \mathrm{DV}=$ dependent variable $; \mathrm{IV}=$ independent variable $; \mathrm{M}=$ mediating variable $\mathrm{CI}=$ confidence interval

$* \mathrm{p}<0.1 * * \mathrm{p}<0.05 ; * * * \mathrm{p}<0.01$ 